\title{
Legal Exploration of IPO Information Disclosure System under the Background of Future Registration System
}

\author{
Shi Wenhao \\ Wuhan University of Technology \\ Wuhan, China
}

\begin{abstract}
The core content of the registration system is information disclosure, so information disclosure supervision has become an important task in the pilot of future registration system. Existing IPO information disclosure system has imperfect legislation and too concentrated regulatory system. There are two important aspects in this paper: first of all, from the perspective of the laws, regulations and supervision system, laws and regulations related to comparative analysis of the present stage of information disclosure system and supervision system, it found that our country present stage IPO on the problems existing in the information disclosure system, and then according to the specific cause of these problems, this paper also combined with the development of our country present stage, and put forward several pilot in the future when registration system should be improved.
\end{abstract}

Keywords-Registration system; IPO; Information disclosure system; Stock market regulation

\section{INTRODUCTION}

November 5, 2018, at the opening ceremony of the first China international import expo, Chinese President xi jinping mentions the establishment of a science and innovation board and pilot registration system on the Shanghai stock exchange, to support the construction of the Shanghai international financial center and the center for science and technology innovation, and constantly improve the capital market system. The significance of the establishment of science and technology innovation board is to cultivate China's worldcompetitive science and technology companies. The registration system will be piloted under the science and technology innovation board, which is in line with the global financial market. The key to the implementation of the registration system lies in the full and effective information disclosure system, which is the basis of market pricing and the premise of investors' value judgment. This paper intends to start with the current situation of stock issue information disclosure system, analyze the problems of the existing disclosure system, and put forward the fetters and shackles that should be broken in the future trial registration system of science and technology innovation board.

\section{STATUS QUO OF IPO INFORMATION DISCLOSURE SYSTEM IN CHINA}

\section{A. Legislative status}

The current legal and regulatory system of information disclosure in China is mainly divided into four parts: laws, administrative regulations, departmental rules and normative documents. The laws most closely related to the information disclosure system are the securities law and the company law. These two laws are the programmatic documents in the information disclosure of listed companies, which clearly stipulate what IPO needs to disclose and effectively regulate the securities market and the process of securities information disclosure. The administrative regulations only include the most recently revised "stock regulations" in 1993, while the departmental regulations are the "measures on the administration of stock exchanges" in 2001 and the "measures on the administration of initial public offering of stocks and listing on the gem" in 2014.Other normative documents including "about IPO prospectus online company notice disclosure of related matters," securities offering sponsor business management ", "about to further improve the quality of IPO company financial information disclosure's opinions on relevant issues, the China securities regulatory commission on further promoting the opinions of the IPO reform", "about initial public offering and in the prospectus related to the profitability of listed companies information disclosure guidelines", "sponsors due diligence investigation guide", "public offering of securities such as corporate disclosure content and format guidelines, the securities issuance and underwriting management" and "Measures on the administration of initial public offering and listing of stocks." In addition, the stock exchange and the industry association formulate the self-regulatory documents also become a part of the information disclosure of the company to be listed.

\section{B. Current situation of supervision}

At present, Chinese supervision system is the same as the international mainstream securities supervision and management system, which is formed by the cross-integration of self-regulation and government supervision and management. However, due to the particularity of China's national conditions, the government regulation system takes up 
a large proportion, and the industry self-regulation plays a more complementary and auxiliary role.

Chinese securities regulatory commission (hereinafter referred to as CSRC) is an administrative organ responsible for unified supervision and administration of the national securities and futures market and maintenance of the order of the securities and futures market. For work in the proposed disclosure of listed companies, securities regulatory commission (CSRC) mainly embodied in the following four aspects: the duty of draft and publish the relevant information disclosure in the process of the normative documents, review the IPO plans to release the information disclosed by the company, according to plans to release the information disclosed by the company to agree with the issue of the administrative decision, to be issuing company in the field of information disclosure irregularities shall be given administrative punishment. In terms of administrative penalty, CSRC gives warning, fine, confiscation of illegal income, market entry ban and other penalties to the company or relevant responsible personnel who violate the information disclosure rules and regulations. No matter from the legislation design to the practical operation, CSRC realizes its supervision function at every step, which realizes the centralized management supervision mode.

The stock exchange has the right to review the materials of the company to be listed. Under a 2005 amendment to the securities law, IPO issuance and review are separated and exchanges are given the power to set higher standards for listing conditions than those set out in article 50 of the law. The company to be listed can only enter the new share subscription procedure after the stock exchange examines and approves the disclosed materials.

Self-discipline supervision is mainly divided into two parts: intermediary agency supervision and industry association supervision. IPO intermediaries generally include securities companies, law firms, accounting firms and capital verification agencies. The materials of the company to be listed in the IPO process must be reviewed and approved by the above institutions. After the materials are complete, securities companies with underwriting qualifications are required to provide guidance and underwriting. Intermediary institutions run through the whole IPO process of the company to be listed, and their supervision over information disclosure of the company to be listed is the closest and most timely. Industry association supervision mainly refers to the China securities industry association, the association of certified public accountants and the association of lawyers. The above associations guarantee the accuracy and authenticity of information disclosure made by the company to be listed through restraining and supervising intermediary institutions, and urge intermediary institutions to be diligent and responsible, which belongs to secondary supervision.

\section{PROBLEMS EXISTING IN THE CURRENT IPO INFORMATION DISCLOSURE SYSTEM}

\section{A. The current law has a low rank and poor applicability}

At present, only the securities law and the company law are the basic laws on IPO information system, and most of the other laws are the rules or other normative documents issued by CSRC, which make the standard system of stock issue information disclosure excessively focus on low-level norms, and sometimes it is difficult to carry out strong information disclosure supervision. The operability of the current law is poor and the disclosure standards are defective. China's current "securities law" for IPO information disclosure provisions for the guidance nature, in the actual IPO process and can not play its due guidance and regulation role. The legislation takes "materiality" as the criterion of information disclosure, which has greater subjectivity. Due to the high repeatability of this standard in legislation in China, whether the level of effectiveness is high or low, it is involved, resulting in the application of this standard is completely controlled by the CSRC and has greater subjectivity. In terms of responsibility, the content of legislation is weak in standardization, there are overlapping and contradictory situations, and some legal liabilities are not accurate enough and the punishment for illegal ACTS is relatively light. Article 63 of the securities law only stipulates in principle the information disclosure of listed companies, but it does not clearly stipulate the subject of liability, scope of liability, defense reasons for exemption from liability and other related matters for the misstatement, which weakens the practical operability. The legal liability for disclosure violations such as false disclosure and fraudulent listing is relatively light, with low cost of violation and weak deterrent effect. In view of this, in the pilot registration system, inadequate legislative regulation is an urgent problem to be solved.

\section{B. The scope of CSRC's examination is too broad}

Under the current approval system, the CSRC's strict control starts from the "birth" stage, namely IPO stage, to the "death" stage, namely exit from the stock market stage. In the initial stage of IPO, China has formulated the pre-disclosure system for the companies to be listed, which means that after the CSRC accepts the IPO application, the issuing company is required to make information disclosure, rather than after the audit is completed. $\mathrm{Li}$ dongfang, a professor at China university of political science and law, believes that predisclosure is an expansion of the scope of application of information disclosure system, which to some extent increases the disclosure burden of issuers. For example, in the predisclosure stage, the proposed issuing company is required to state the purpose of the funds raised in the prospectus. In practice, there are not a few companies that have not been approved to issue shares due to the lack of reasonable or clear explanation of the use of funds raised. As an internal financial plan of the company, the direction of fund raising flow is part of its internal operation. Besides, the market is changing rapidly, so it is reasonable for the applicant company to change its operation strategy due to other market factors after the approval and issuance. 


\section{The role of self-regulation needs to be improved}

First of all, as has the right of public audit securities exchanges, although it has the authorization of the "securities law", but because the law is not detailed the exercise time and exercise of power, lead to the right to audit is essentially a pattern, because to listed companies must after the CSRC multifarious and strict examination as to substance to the next step of public audit, in fact largely caused public right of audit by the CSRC "hogging"; Secondly, securities self-regulatory organizations lack independence and have a strong administrative nature. They are not strictly market regulators. Because the "securities law" did not for self-discipline supervision system, causes and the securities and exchange of unclear division of responsibility itself is affected by the CSRC and the stock exchange and the securities association regulation, so only a limited stock exchange and the securities association of auxiliary supervision function, and centralized management, by securities regulatory commission on the surface of the secondary regulation essentially only the CSRC "dominance"; Finally, some intermediaries in the securities market are not only not self-regulatory regulators, but also "connivers" or even "accomplices" of illegal information disclosure. The issuance of false capital verification reports by asset appraisal agencies and the concealment of major financial information by accounting firms have made it more difficult to identify the "camouflage veil" of information of the companies to be issued, which has seriously damaged the interests of investors.

\section{PATH EXPLORATION OF IPO INFORMATION DISCLOSURE SYSTEM UNDER CHINA'S REGISTRATION SYSTEM}

\section{A. Improve the legal system of information disclosure system}

A sound legal system is the basis for ensuring the sound development of the securities market. The existing information disclosure system of stock issuance in China is simply and repeatedly scattered in the legislation of various classes. Taking "materiality", the standard of information disclosure, as an example, both the securities law with the highest level of effectiveness and the self-made rules of the two major stock exchanges with the lowest level of effectiveness are involved, and most provisions are concentrated in documents with lower level of effectiveness. Among them, different documents have different interpretations of the standard of "materiality", which are respectively summarized as major events, major events and major adverse factors by the author. It can be seen that the legislation is highly repetitive. The applicability of stock issue information disclosure is seriously affected by the low level of normative effectiveness and high article repeatability. In addition, in the current legislation, relevant information disclosure regulations mainly focus on the continuous disclosure of information of listed companies in the secondary market. By contrast, regulations on issuing information disclosure are relatively scarce, and legislation needs to be improved urgently. The regulations on information disclosure system of stock issuance should uniformly stipulate that the level of legislation and its applicability should be improved in the securities law. The nature and supervision responsibilities of the CSRC should also be stipulated in the legislation, and the authorization clauses should be given to the state organs with certain administrative supervision functions, such as the national development and reform commission. As for the specific specification of disclosure format, it is suggested that the ownership of issuance audit and listing audit rights should be determined respectively by the CSRC and securities trading departments in the form of regulations and industry norms.

Establish a legal liability system commensurate with the obligation of information disclosure. The "entrance" with loose registration system must have strict supervision. In view of the current situation in China, the legal liability is relatively light. Drawing on the relevant experience of the United States and Japan, the securities law was amended to increase the penalty range for false disclosure, and the current penalty standard of 600,000 yuan was raised to 1 million to 10 million yuan. For issuers and intermediary institutions that cheat the listing and seriously damage the interests of investors, we should increase the punitive compensation mechanism to deter issuers. In addition to increasing the intensity of punishment, the legal responsibility of intermediary agencies should also be increased. At present, most cases of false disclosure and fraudulent listing punish the representative, and extend the punishment to the intermediary agency where the representative is located. Administrative penalties such as fine or market ban can have a good effect to a certain extent. In addition, strengthen the criminal responsibility, knowingly and deliberately conceal, participate in the issuer's fraudulent issuance of intermediary institutions and relevant practitioners also included in the scope of criminal penalties for securities fraud. In a word, the authenticity, effectiveness and comprehensiveness of information disclosure should be ensured through perfect supervision of administrative sanctions, civil liability and criminal liability.

\section{B. Build a multi-level regulatory system}

The CSRC shall decentralize power, re-define the division of labor between the government and the market, clarify the boundaries between the security's regulatory authorities, exchanges and the market, and expand the power of the stock exchanges. Change the role of the exchange as a vassal and enhance its independence. At present, the situation is that the stock exchange is on the front line of supervision for information disclosure of stock issuance by listed companies, but the stock exchange does not have the right to investigate and needs to report to the CSRC, which extends the supervision front. If the stock exchange is given the right to investigate illegal behaviors such as false disclosure, and the stock exchange is urged to assume greater responsibilities in ensuring the accuracy of information, the CSRC and the stock exchange will gradually realize the two-level supervision of stock issue information disclosure, which will ensure more effective information disclosure.

In addition, effective supervision of intermediary institutions should be incorporated into the regulatory system, and the power of supervision of intermediary institutions should be appropriately endowed. Our country "securities law" provisions of sponsors, accounting firms and law firms shall perform the obligation of due diligence, but does not give relevant intermediary supervision power, thus can give relevant intermediary agencies must be appropriately investigative and size-of-the-party, let the law firm, accounting firm and other 
intermediary agencies in the prospectus and the application materials ready to play a bigger role. Of course, intermediary institutions with effective regulatory functions need marketoriented and highly autonomous self-regulatory organizations, so self-regulatory organizations should be de-administrated. In this way, an administrative and market supervision system has been formed for information disclosure of stock issuance, which can effectively guarantee the quality of information disclosure under the registration system.

\section{Strengthen the internal governance of the company and establish the information disclosure credit system}

Improving the quality of information disclosure requires joint efforts of internal and external supervision. External supervision provides institutional supply, but it also requires self-restraint from within the company. The law should specify the duty of good faith of the controlling shareholder of the company. The controlling shareholder of a company has the dominant right over the decision-making and operation and management of the company, and should undertake more obligations according to the principle of consistent rights and responsibilities. Second, due to the dominant position of controlling shareholder, is likely to own will rise in the form of a resolution by the shareholders meeting for the company's will, make illegal information disclosure, the behavior of the fraud issue, violate the rights and interests of minority shareholders, based on the rule of law concept of justice, by attaching to the controlling shareholder, the good faith obligation to fix shareholder decision-making gap is caused by injustice. In accordance with the principle of good faith, the company may not engage in illegal activities to harm the interests of investors through resolutions of the general meeting of shareholders. However, in commercial activities, some controlling shareholders issue shares by controlling the company to issue false information, engage in speculative behavior, make a lot of money and then run away, seriously damaging the interests of minority shareholders and investors. Our current law does not specify the controlling shareholder's fiduciary duty, to big shareholders to create opportunities for speculation, so be explicitly stipulated in the law the controlling shareholder's fiduciary duty, must not manipulate companies such as false statement, in addition to provisions of criminal law the obligation of good faith legal responsibility, even though the criminal legal liability to establish credit mechanism of controlling shareholders. Thirdly, the qualifications of directors, supervisors and senior management personnel of the company are linked to whether there is any illegal disclosure of the company, to make directors, supervisors and senior executives serve assiduously, supervise the company's behavior, and avoid the occurrence of illegal information disclosure and fraudulent issuance.

\section{CONCLUSION}

It is an important measure for our country to move towards mature capital market to try out registration system in science and technology innovation board. However, the current IPO information disclosure system has many problems in both the legislative system and specific regulatory measures. This paper starts with legislation and supervision, and puts forward the future improvement path under the pilot of Shanghai science and technology innovation board registration system. To form a multi-level supervision mode that is dominated by the supervision of national securities regulatory organs, coordinates with the self-regulation of stock exchanges, and gives full play to the advantages of various institutions in society. In order to achieve the balance between supervision and market selection, the pilot registration system on the board of science and technology innovation should be combined with the current situation of China's stock market, and the advantages and disadvantages of both should be comprehensively considered, rather than the absolute exclusion or application.

\section{REFERENCES}

[1] Shen zhaohui: power distribution of securities law, Peking University press, 2016. (In Chinese)

[2] Miao yinzhi: research on the implementation mechanism of China's securities law, Peking University press, 2017. (In Chinese)

[3] Zhang jingbo: review on supervision and regulation of stock issuance information disclosure in China from the perspective of registration system reform [J]. Southwest finance,2018(07):46-52. (In Chinese)

[4] Calmness: decentralization and reorganization of issuance audit and supervision under the registration system [J]. Law review,2016,34(01):171-178. (In Chinese)

[5] $\mathrm{Li}$ wenhua: an analysis on the supervision of information disclosure under the Chinese registration system [J]. Southwest finance,2015(03):34-37. (In Chinese)

[6] Zhou yousu, Yang zhaoxin: reflection and reconstruction of China's stock issue information disclosure system under the background of registration system reform [J]. Economic system reform,2015(01):146150. (In Chinese) 